\title{
Controlled study of the efficacy ozone therapy in Fibromyalgia, a randomised controlled trial [abstract]
}

\author{
Ziad Fahmy \\ Augusta Clinic for Rheumatic Diseases, Physical. Med. And Rehabilitation, Germany
}

\section{ABSTRACT}

\section{○ OPEN ACCESS}

\section{Citation}

Famy Z. Controlled study of the efficacy ozone therapy in Fibromyalgia, a randomised controlled trial [abstract]. Proceedings of The World Conference on Ozone Therapy in Medicine, Dentistry and Veterinary. Ancona (Italy). September 22nd - 23rd - 24th , 2017. J Ozone Ther. 2019;3(4):20. doi 10.7203/jo3t.3.4.2019.15424

Academic Editor Jose Baeza-Noci,

School of Medicine, Valencia University, SPAIN

\section{Editor}

World Federation of Ozone Therapy, Bolgna, ITALY

\section{Received}

June 17, 2019

\section{Accepted}

December 08, 2019

Published

December 30, 2019

\section{Intellectual Property}

Ziad Fahmy.

This is an open access article distributed under the terms of the Creative Commons Attribution License (CC BY 4.0), which permits unrestricted use, distribution, and reproduction in any medium, provided the original author and source are credited

\section{Author Information}

Email: dr.ziad.fahmy@gmx.de
Introduction. Fibromyalgia meaning muscle and connective tissue pain it a disorder classified by the presence of chronic widespread pain and a heightened and painful response to gentle touch (tender points).

Other core features of the disorder include debilitating fatigue, sleep disturbance, and joint stiffness.

Purpose. The aim of the study is to see the efficacy of ozone in relation to other local anaesthetic and placebo for relief of pain.

Patients and methods. The Study involved 300 patients with classical Fibromyalgia (ACR criteria) age between 45 and 70 .

The first group treated only with ozone 2 - 3 x per week for over 4 necks (15 $\mathrm{mcgr} / \mathrm{mL}$ )

The second group with local anaesthetic /Lidocain $2 \% 10-20 \mathrm{~mL}$ )

The third group, placebo.

Several clinical parameters were monitored during a demonstration in 4-6 weeks.

The clinical examination included vital signs, pain using visual analog Scale, Duration of morning stiffness, night pain, NSAID consumption.

\section{Results and Conclusion.}

1. Ozone has significant effect in Fibromyalgia in relation to the other two groups.

2. Function index improved in both groups ozone and anaesthetic.

3. Ozone treatment is a safe therapy compared to the local anaesthetic 